\title{
A Model System of the Dynamic Loading Occurring in Synovial Joints: The Biological Effect of Plowing on Pristine Cartilage
}

\author{
M. Rita Correro-Shahgaldian ${ }^{a}$ b Chafik Ghayor ${ }^{b} \quad$ Nicholas D. Spencer ${ }^{c}$ \\ Franz E. Weber ${ }^{\mathrm{b}}$ Luigi M. Gallo ${ }^{\mathrm{a}}$ \\ ${ }^{a}$ Clinic for Masticatory Disorders, Removable Prosthodontics and Special Care, Center for Dental Medicine, \\ University of Zurich, ${ }^{b}$ Oral Biotechnology and Bioengineering, Division of Cranio-Maxillofacial and Oral Surgery, \\ University Hospital Zurich, Center for Dental Medicine, University of Zurich, and ' Laboratory for Surface Science and \\ Technology, Department of Materials, ETH Zurich, Zurich, Switzerland
}

\section{Key Words}

Synovial joint · Cartilage · Plowing · Biomechanics .

Biochemistry - Chondrocytes - Gene expression .

Extracellular matrix

\begin{abstract}
Mechanical stress is listed as a main risk factor for cartilage degradation. The aim of this study was to investigate the biological response of cartilage to dynamic loading such as plowing. Cartilage strips harvested from bovine nasal septum were submitted to plowing using a cylindrical indenter, applying a constant normal force in the vertical axis and moving at constant speed in the horizontal axis. After plowing, cell viability, gene expression and glycosaminoglycan (GAG) release were measured with conventional assays. The cell-viability assay and qRT-PCR showed that plowing induces cell death and matrix metalloproteinase 3 (MMP-3) upregulation. The addition of actinomycin $D$, before or after plowing, confirmed that plowing was responsible for the observed MMP-3 upregulation. Even if the transcriptions of the tissue inhibitor of metalloproteinase (TIMP-1), aggrecan (Agg), collagen type I (Coll1), collagen type II (Coll2) and fibronectin (Fn) were not significantly affected by plowing, actinomycin $\mathrm{D}$ treatment revealed that plowing induces a strong increase in TIMP-1 and Coll1 messenger RNA content
\end{abstract}

and influences the gene regulation of Agg, Coll2 and Fn. Furthermore, plowed cartilage explants exhibited enhanced GAG release. Application of hydroxamate MMP inhibitor after loading showed that plowing induces GAG release via the activation of catabolic enzymes. Plowing causes cell death of the chondrocytes closer to the surface as well as matrix damage, observed as GAG loss. Moreover, in healthy chondrocytes, plowing promotes the production and activation of catabolic enzymes like MMP-3.

c) 2015 S. Karger AG, Basel

\begin{tabular}{ll}
\hline Abbreviations used in this paper \\
\hline 18S-rRNA & $\begin{array}{l}\text { 18S ribosomal RNA } \\
\text { aggrecan }\end{array}$ \\
Agg & $\begin{array}{l}\text { collagen type I } \\
\text { Coll1 }\end{array}$ \\
Coll2 & collagen type II \\
DMEM & Dulbecco's modified Eagle's medium \\
Fn & fibronectin \\
GAG & glycosaminoglycan \\
GAPDH & glyceraldehyde 3-phosphate dehydrogenase \\
GM6001 & hydroxamate matrix metalloproteinase inhibitor \\
MMP-3 & matrix metalloproteinase 3 \\
mRNA & messenger RNA \\
TIMP-1 & tissue inhibitor of metalloproteinase \\
TMJ & temporomandibular joint
\end{tabular}

\section{KARGER}

E-Mail karger@karger.com

www.karger.com/cto
(C) 2015 S. Karger AG, Basel

1422-6405/15/1996-0364\$39.50/0
Franz E. Weber

Oral Biotechnology and Bioengineering

Universitätsspital, Frauenklinikstrasse 24

CH-8091 Zürich (Switzerland)

E-Mail franz.weber@zzm.uzh.ch 


\section{Introduction}

Over time, mechanical stress is one of the causes of cartilage degradation. In order to understand the pathomechanics of cartilage breakdown that occurs in the synovial joints, the response of cartilage to mechanical loading has been extensively studied by means of several laboratory models [Kurz et al., 2005]. Interestingly, it has been reported that moderate loading helps cartilage homeostasis [Lane et al., 2000; Griffin and Guilak, 2005; Dossumbekova et al., 2007; Torzilli et al., 2010] but that injurious overload contributes to or causes cartilage degradation [Patwari et al., 2001; Chen et al., 2003; Patwari et al., 2003; DiMicco et al., 2004; Lin et al., 2004; Lee et al., 2005; Sauerland and Steinmeyer, 2007; Verteramo and Seedhom, 2007; Ding et al., 2010]. Chen et al. [2003] showed that continuous or intermittent uniaxial loads of varying durations and magnitudes applied to bovine articular cartilage explants caused chondrocyte death and collagen damage. DiMicco et al. [2004] reported that uniaxial unconfined compression of bovine articular cartilage explants caused proteoglycan degradation and the subsequent loss of glycosaminoglycans (GAGs). Moreover, uniaxial cyclic loading of cartilage explants leads to cell death, collagen damage and GAG loss. It has also been shown that long-term mechanical stress causes an increase in the activity of stromelysin 1 /matrix metalloproteinase 3 (MMP-3) [Lin et al., 2004]. Other groups [Lee et al., 2005; Fitzgerald et al., 2006; Sauerland and Steinmeyer, 2007; Verteramo and Seedhom, 2007; Ding et al., 2010] have reported that static compression of articular cartilage explants causes specific, time-dependent changes in chondrocyte gene expression, and that cyclic uniaxial compression or shear stress regulates clusters of functionally related gene patterns. Although these in vitro models reproduce the mechanical stresses that cartilage experiences in vivo and provide insights into the biological response of such a complex tissue to mechanical injuries, their uniaxial design presents some limitations.

In a previous study, we studied the temporomandibular joint (TMJ) disk deformations that occur during mandibular function by means of novel, 3-dimensional modelling software that processes data acquired by magnetic resonance imaging and jaw tracking (a system that allows observation of mandibular movement dynamically) [Palla et al., 2003; Gallo, 2005; Gallo et al., 2006]. These TMJ disk measurements were used to develop a rolling/plowing explant test system that is able to mimic the in vivo plowing effect that results from the combination of com- pression and sliding of the mandibular condyle on the TMJ cartilage disk [Colombo et al., 2011].

We report here on the biological response of bovine nasal septum cartilage to plowing, by studying chondrocyte viability, variations in gene expression and GAG release.

\section{Materials and Methods}

\section{Harvesting of Cartilage Explants}

The nasal septa of 12-month-old calves were provided by a local abattoir within $4 \mathrm{~h}$ of slaughter. Under sterile conditions, control cartilage explants $(20 \times 30 \times 2 \mathrm{~mm})$ and cartilage strips $(60 \times$ $17 \times 2 \mathrm{~mm}$ ) were harvested by using a 'dual-parallel-blade cartilage cutter'. Control samples and cartilage strips were washed in Dulbecco's PBS (Invitrogen, Carlsbad, Calif., USA) and equilibrated overnight in Dulbecco's modified Eagle's medium (DMEM; Invitrogen) supplemented with $10 \%$ fetal bovine serum (Sigma, St. Louis, Mo., USA), 10 mM HEPES (Sigma), nonessential amino acids $(0.1 \mathrm{~mm})$, penicillin $(100 \mathrm{units} / \mathrm{ml})$, streptomycin $(100 \mu \mathrm{g} / \mathrm{ml})$ and amphotericin B $(0.25 \mu \mathrm{g} / \mathrm{ml})$.

\section{Plowing of Cartilage Strips}

Before plowing, the cartilage strips were glued at their ends to Plexiglas supports with cyanoacrylate glue. The plowing was performed unidirectionally in DMEM for $2 \mathrm{~h}$ at $37^{\circ} \mathrm{C}$ in a sterile hood, using a stainless-steel, nonrotating, cylindrical indenter $(25 \mathrm{~mm}$ in diameter), moving in the horizontal axis with a constant speed of $10 \mathrm{~mm} / \mathrm{s}$ and simultaneously compressing the cartilage in the vertical axis by applying normal forces of 25, 50 or $100 \mathrm{~N}$.

The indenter stroke length was $40 \mathrm{~mm}$ and the total number of plowing cycles was 500. During plowing, the control cartilage was placed as a free-swelling explant in the medium in which the cartilage strip was located.

After plowing, using a blade, the cartilage subexplants $(15 \times 15$ $\times 2 \mathrm{~mm}$ ) were collected from both the plowed strip and the freeswelling control, and were subjected to analysis.

\section{Chondrocyte Viability Assay}

Following plowing (at 25, 50 or $100 \mathrm{~N}$ of applied normal force), the cartilage was sliced into 500- $\mu \mathrm{m}$ sections, rinsed in Dulbecco's PBS and incubated for $20 \mathrm{~min}$ in DMEM containing $1 \mu \mathrm{g} / \mathrm{ml} \mathrm{cal}-$ cein acetoxymethyl ester (live-cell staining; Sigma) and $1 \mu \mathrm{M}$ ethidium homodimer (dead-cell staining; Sigma). The treated slices were thereafter transferred into fresh DMEM. Fluorescence-microscopy images were acquired at 515 and $635 \mathrm{~nm}$ by means of an inverted fluorescence microscope (Zeiss, Axiovert 200) equipped with a digital camera.

\section{RNA Extraction and $q R T-P C R$}

After plowing at 25, 50 and $100 \mathrm{~N}$ of applied normal force, the cartilage subexplants collected from the plowed strips and from the controls were equilibrated for 2,4 or $24 \mathrm{~h}$ in DMEM at $37^{\circ} \mathrm{C}$. Upon equilibration, samples were snap-frozen in liquid nitrogen and stored at $-80^{\circ} \mathrm{C}$. RNA extraction was performed according to Davidson et al. [2006] with some modifications. Finely sliced cartilage subexplants (approx. $50 \mathrm{mg}$ ) were placed in Eppendorf tubes and 
homogenized twice for $1 \mathrm{~min}$ in $800 \mu \mathrm{l}$ of TRIzol reagent (Invitrogen). After 5 min of equilibration at room temperature, $200 \mu \mathrm{l}$ of chloroform was added and the tubes were vigorously shaken, mixed and incubated for $2 \mathrm{~min}$ at room temperature. Following centrifugation at $9.5 \mathrm{~g}$ for $30 \mathrm{~min}$ at $4{ }^{\circ} \mathrm{C}$, the obtained aqueous phases were recovered, extracted with $200 \mu \mathrm{l}$ of chloroform and treated as previously described. The recovered supernatants were transferred into 2 -ml tubes, gently mixed with $500 \mu \mathrm{l}$ of isopropanol, incubated for $10 \mathrm{~min}$ at room temperature and subsequently centrifuged at $9.5 \mathrm{~g}$ for $40 \mathrm{~min}$ at $4^{\circ} \mathrm{C}$. The supernatants were discarded and the pellets were resuspended in $900 \mu \mathrm{l}$ of lysis buffer (RNeasy mini kit ${ }^{\circledR}$; Qiagen $\mathrm{GmbH}$, Hilden, Germany) supplemented with $90 \mu \mathrm{l}$ of $\beta$-mercaptoethanol (Sigma-Aldrich). After adding $900 \mu \mathrm{l}$ of ethanol (75\%), the RNA was purified using an RNeasy mini kit, while genomic DNA was digested with a DNase kit (Qiagen) according to the manufacturer's instructions. Reverse transcriptions of RNA were performed with random hexamer primers using a 1st-strand cDNA synthesis kit for RT-PCR with avian myeloblastosis virus (Roche Diagnostics AG, Rotkreuz, Switzerland) according to the manufacturer's instructions. qRT-PCR of the obtained complementary DNA was performed in 96-well plates by means of an iCycler real-time detection system ${ }^{\circledR}$ (iQ5Bio-Rad Laboratories, Hercules, Calif., USA) and the reactions were carried out using a QuantiFast ${ }^{\mathrm{TM}}$ SYBR ${ }^{\circledR}$ Green PCR kit (Qiagen). The primers used were the same as those reported in Fitzgerald et al. [2006]. They were designed for the amplification of selected target genes: the extracellular matrix proteins aggrecan (Agg), collagen type I (Coll1), collagen type II (Coll2), fibronectin (Fn), the catabolic enzyme MMP-3 and its inhibitor [the tissue inhibitor of metalloproteinase (TIMP-1)] and the housekeeping genes glyceraldehyde 3-phosphate dehydrogenase (GAPDH) and $18 \mathrm{~S}$ ribosomal RNA (18SrRNA). Housekeeping genes as controls from treated samples and a gene of interest from untreated control samples were run on every plate for normalization purposes. The gene regulation was calculated as a multiple, by using the comparative threshold cycle $(\Delta \Delta \mathrm{Ct})$ method. Thus, a gene was considered to be upregulated when the multiple of expression was $>2$ and downregulated for values $<0.5$.

\section{GAG Release}

In order to measure the GAG release following plowing, cartilage subexplants were collected from strips plowed at $100 \mathrm{~N}$ of applied normal force and from free-swelling controls. The samples were incubated in DMEM at $37^{\circ} \mathrm{C}$ in the course of 4 different periods of equilibration (i.e. over 1, 2, 3 or 4 days) after plowing. At each time point, cartilage subexplants and $1 \mathrm{ml}$ of the corresponding culture medium were collected and stored at $-20^{\circ} \mathrm{C}$ until a DMMB (1-9-dimethylmethylene blue; Sigma) assay was performed [Barbosa et al., 2003]. GAG measurement in the media was carried out according to Jeffrey and Aspden [2007]. Briefly, $50 \mu \mathrm{l}$ of appropriately diluted medium samples or chondroitin-sulphate A $(10-100 \mu \mathrm{g} / \mathrm{ml}$; Sigma) standard were mixed with $1 \mathrm{ml}$ of DMMB solution [16 mg/l DMMB in $0.2 \mathrm{M}$ guanidine hydrochloride, $1 \mathrm{~g} / \mathrm{l}$ sodium formate and $1 \mathrm{ml} / \mathrm{l}$ formic acid]. The absorbance at $525 \mathrm{~nm}$ was immediately read in triplicate in a 96-well plate using a spectrophotometer plate reader (Synergy HT Multi-Mode Microplate Reader, BioTek).

\section{Inhibition Experiments}

To confirm that the change of chondrocyte gene expression was induced by plowing, 2 different experiments were performed.
(1) Cartilage strips and controls were incubated in DMEM supplemented with $30 \mu \mathrm{M}$ transcription inhibitor actinomycin D (Sigma) for $2 \mathrm{~h}$ before plowing. The strips were then plowed for $2 \mathrm{~h}$ with $100 \mathrm{~N}$ of applied normal force. In this experiment, the effect of plowing on gene expression was blocked so that no difference with regard to the controls was expected if gene expression changes were due to mechanical loading. (2) Conversely, cartilage strips were plowed for $2 \mathrm{~h}$ with $100 \mathrm{~N}$ of applied normal force and then incubated for $2 \mathrm{~h}$ with the transcription inhibitor. The control cartilage was subjected to the same treatment in the inhibitor. In this case, we would detect only those genes expressed during plowing. After both experiments, gene expression of MMP-3, TIMP-1, Coll1, Agg, Fn and Coll2 was determined by qRT-PCR.

To confirm that plowing causes GAG release by activating catabolic enzymes, experiments of MMP inhibition were performed by using hydroxamate MMP inhibitor (GM6001; Millipore, Bedford, Mass., USA). Briefly, cartilage strips and free-swelling controls were incubated for $4 \mathrm{~h}$ before plowing in serum-free DMEM supplemented with $1 \%$ SITE (sodium selenite, insulin, transferrin and ethanolamine; Sigma) and containing $10 \mu \mathrm{M}$ GM6001. After $2 \mathrm{~h}$ of plowing at $100 \mathrm{~N}$ of applied normal force performed in serum-free medium, cartilage subexplants ( 3 for each strip) were collected from both control cartilage and the plowed strips and again incubated in DMEM containing GM6001 and SITE for 1,2, 3 or 4 days.

\section{Statistical Analysis}

All experiments were carried out in triplicate, each time from a different nasal septum. Results are expressed as the mean \pm SE. Statistical differences were analyzed using two-way ANOVA and the Student $t$ test.

\section{Results}

\section{Cell Viability}

After plowing the cartilage strips, chondrocyte viability was studied by means of calcein acetoxymethyl ester and ethidium homodimer staining (fig. 1). A layer of dead cells was detected at the surface of the explants. The layers varied in thickness with the magnitude of the applied normal force: they corresponded to 4.6 ( $\mathrm{p}<0.01$ ), 7.3 ( $\mathrm{p}<$ $0.01)$ and $8.7 \%(\mathrm{p}<0.001)$ of the total sample thickness for strips plowed at 25, 50 and $100 \mathrm{~N}$, respectively.

\section{Effect of Plowing on Cartilage Gene Transcription after Equilibration Conducted after Plowing}

Upon plowing completion at 25, 50 or $100 \mathrm{~N}$, cartilage explants from plowed strips and relative controls were equilibrated for 2, 4 or $24 \mathrm{~h}$, and at each time point, the effect of plowing on expression of the selected genes (MMP-3, Fn, Coll1, Coll2, Agg and TIMP-1) was measured using qRT-PCR (fig. 2). 
Fig. 1. Chondrocyte viability after plowing at different applied normal forces. AD Cross sections of control cartilage and strips plowed with applied normal forces of $0,25,50$ and $100 \mathrm{~N}$, respectively (scale bar $=500 \mu \mathrm{m})$. a-d Details of $\mathbf{A}-\mathbf{D}$, respectively (scale bar $=50 \mu \mathrm{m}$ ).
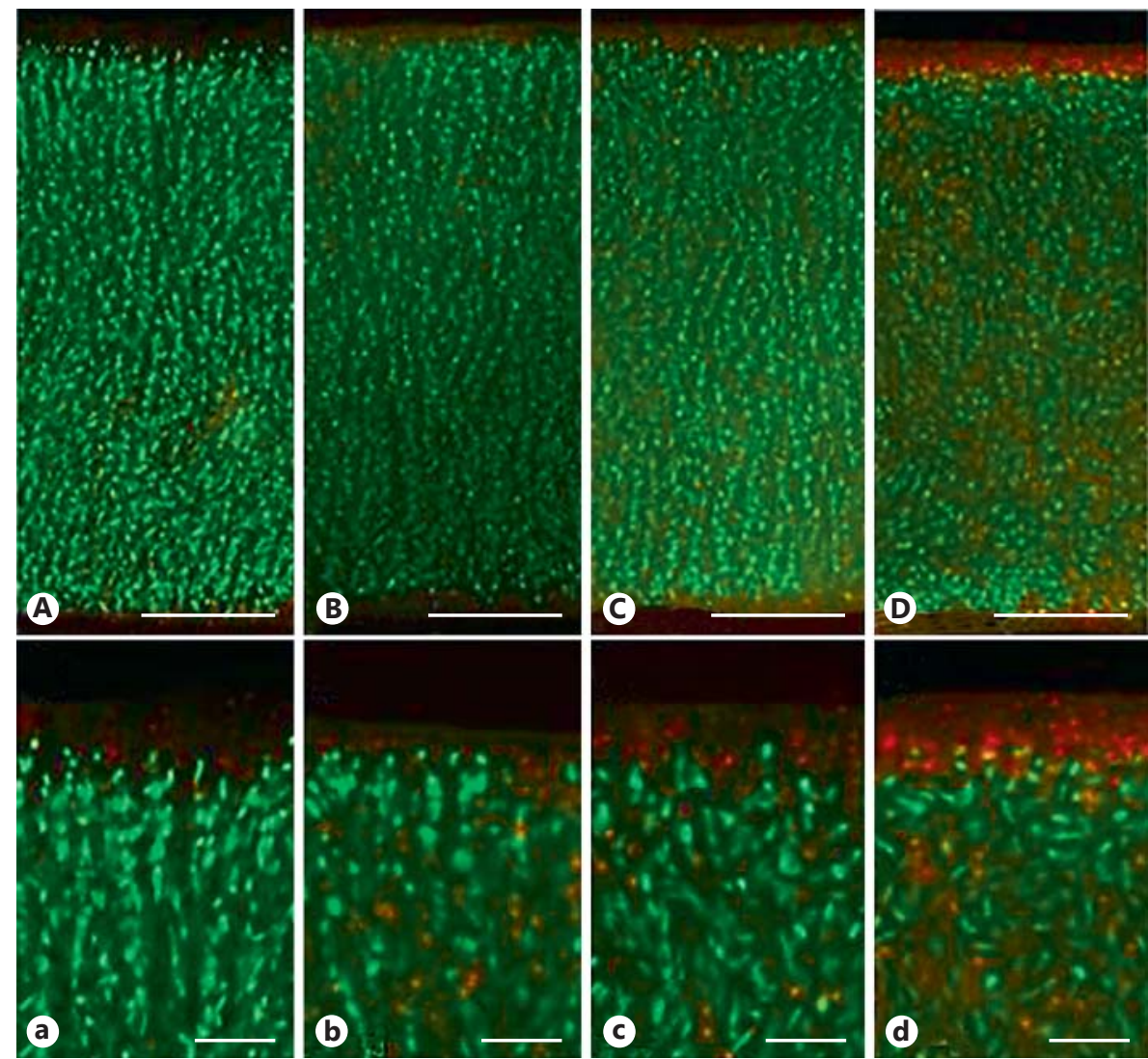

After $2 \mathrm{~h}$ of equilibration, cartilage explants subjected to the 25-newton plowing revealed only a slight change in the MMP-3 messenger RNA (mRNA) synthesis (1.8-fold upregulation) and this value increased (2.3-fold) after $4 \mathrm{~h}$ but then dropped to 0.9 -fold after $24 \mathrm{~h}$.

Furthermore, the cartilage strips subjected to the 50 newton plowing had a 4.7-fold upregulation of MMP-3 after $2 \mathrm{~h}$ of equilibration, and this value decreased over time (4.1-fold after $4 \mathrm{~h}$ and 2.4-fold after $24 \mathrm{~h}$ ).

The upregulation of MMP-3 for the cartilage strip subjected to the 100-newton plowing was stronger: 6.3-fold after $2 \mathrm{~h}, 5$-fold after $4 \mathrm{~h}$ and 3.2 -fold after $24 \mathrm{~h}$ of equilibration conducted after plowing.

In general, the decrease in MMP-3 expression was statistically significant, comparing the expression after 2 and $24 \mathrm{~h}$ for the 25-newton and 100-newton applied normal forces (for $25 \mathrm{~N}: \mathrm{p}=0.0001$, for $50 \mathrm{~N}: \mathrm{p}=0.0700$ and for $100 \mathrm{~N}: \mathrm{p}=0.0075)$.

The plowing at the chosen applied normal forces did not influence the net gene expression of Agg, Fn, TIMP-1, Coll1 and Coll2, the levels of which remained at around the preplowing values (fig. 2).

The Biological Effect of Plowing on Pristine Cartilage

\section{Transcription Inhibition Experiments}

Upon plowing completion and without inhibitor treatment, MMP-3 was upregulated 8.6-fold (fig. 3a), but when the cartilage strips were treated with actinomycin $\mathrm{D}$ for $2 \mathrm{~h}$ before plowing, no MMP-3 upregulation was observed upon plowing completion ( $p=0.0001)$. In contrast, when the treatment with the transcription inhibitor was performed for $2 \mathrm{~h}$ after plowing, MMP-3 was upregulated 7.8-fold (fig. 3b). This value was not different from the MMP-3 expression of plowed cartilage measured after $2 \mathrm{~h}$ of equilibration without actinomycin $\mathrm{D}(\mathrm{p}=0.45)$.

Besides MMP-3 gene regulation, the actinomycin D treatment of cartilage revealed that plowing also influences TIMP-1 expression. Upon plowing completion, TIMP-1 expression was upregulated 1.7-fold (fig. 3a); similarly, when the cartilage strips were preincubated for $2 \mathrm{~h}$ in media containing actinomycin $\mathrm{D}$ and then subjected to the 100-newton plowing, the gene expression of TIMP-1 was increased 2-fold. Moreover, the cartilage incubated in actinomycin $\mathrm{D}$ for $2 \mathrm{~h}$ after plowing induced a strong (7.5-fold) TIMP-1 upregulation ( $\mathrm{p}=0.0010$; fig. $3 \mathrm{~b}$ ). Since qRT-PCR of plowed cartilage strips not 


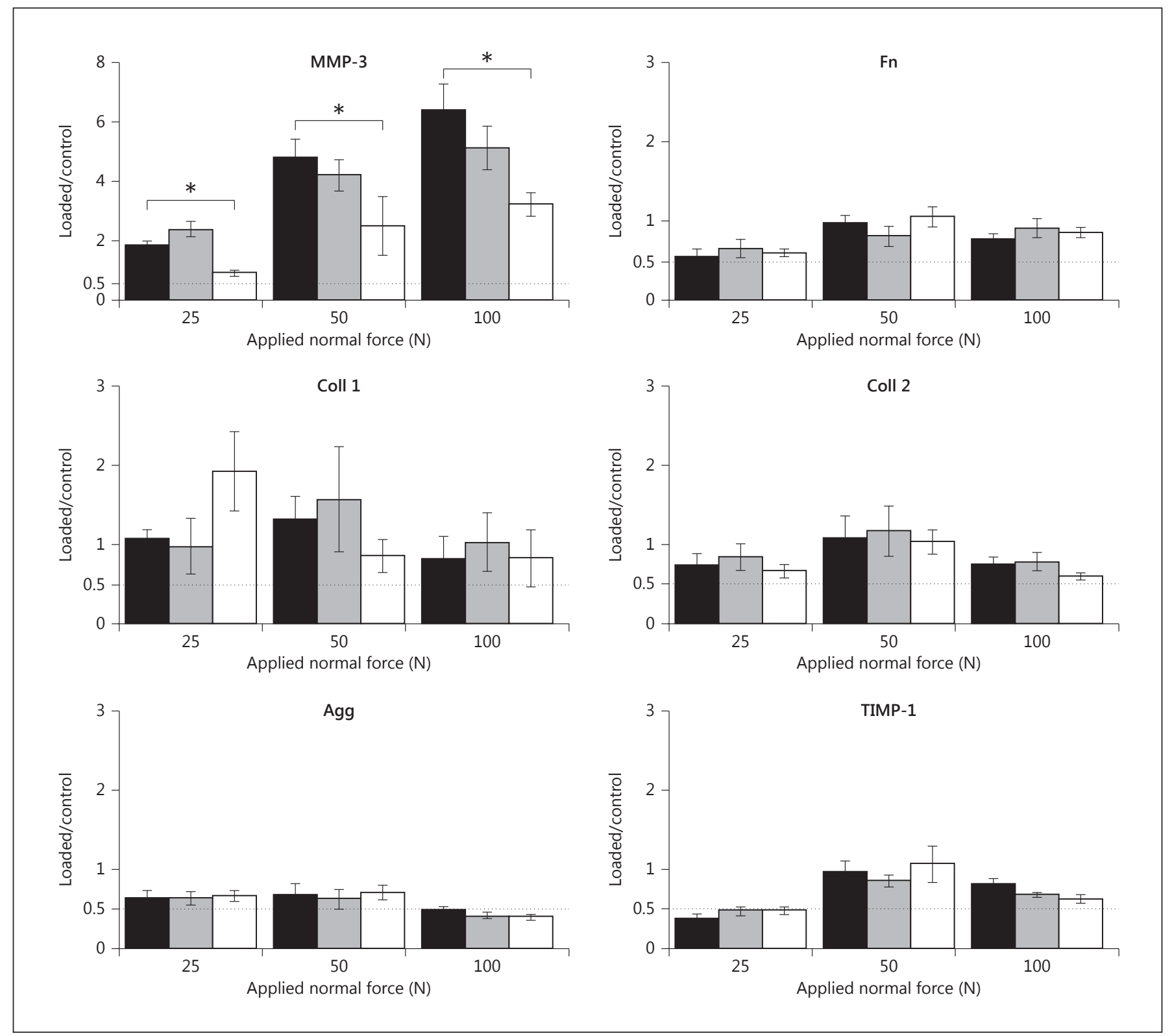

Fig. 2. Gene regulation after plowing with applied normal forces of 25,50 and 100 N. Black bars: gene expression after $2 \mathrm{~h}$ of equilibration after plowing. Grey bars: gene expression after $4 \mathrm{~h}$ of equilibration after plowing. White bars: gene expression after $24 \mathrm{~h}$ of equilibration after plowing. Expression levels (normalized against

the GAPDH and 18S-rRNA genes), are normalized to those of controls (i.e. nonloaded, free-swelling explants). Each experiment was from a separate bovine nasal septum $(\mathrm{n}=3)$, and 3 similarly treated explants were pooled for RNA extraction in each. ${ }^{*} \mathrm{p}<0.05$.

treated with inhibitor revealed that TIMP-1 expression measured after $2 \mathrm{~h}$ of equilibration was unaffected by plowing, these results suggest that when transcription is enabled, the TIMP-1 mRNA content is reduced. The mRNA content of Coll1 was similar to that of TIMP-1, indicating that plowing also reduces the stability of Coll1

mRNA ( $p=0.0010)$. The other studied genes, Agg, Fn and Coll2 which, normally, were only slightly affected or not affected by plowing when no inhibitor was added, showed a different time course. Indeed, when incubation in actinomycin $\mathrm{D}$ was performed either before or after plowing, levels of expression of Agg, Fn and Coll2 remained at 

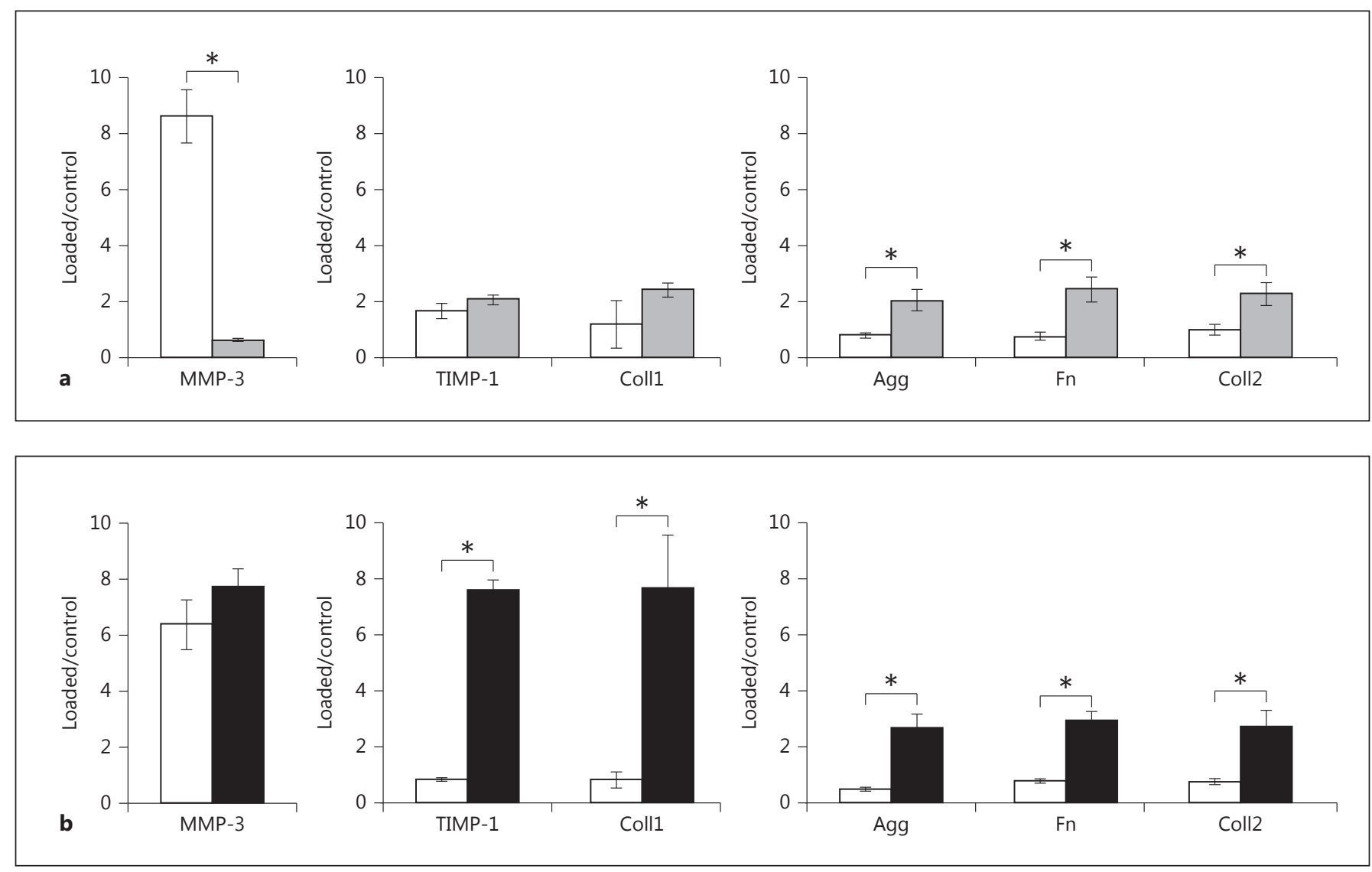

Fig. 3. Gene regulation after 100-newton plowing of cartilage strips, either untreated or treated with actinomycin D. a White bars: gene expression measured immediately after plowing with $100 \mathrm{~N}$ of applied normal force without actinomycin D treatment. Grey bars: before plowing, cartilage strips were incubated with actinomycin D over $2 \mathrm{~h}$. After plowing, the gene expression was measured. b White bars: gene expression measured after $2 \mathrm{~h}$ of equilibration of the cartilage strips were plowed at $100 \mathrm{~N}$ of applied normal force without

around 2 -fold upregulation. In particular, the statistical analysis revealed that the expression of Agg increased due to the treatment with actinomycin $\mathrm{D}(\mathrm{p}=0.009$ and $\mathrm{p}=$ 0.007 for treatment before and after plowing, respectively). Similar behavior was observed for Fn ( $p=0.010$ and $\mathrm{p}=0.017$ for treatment before and after plowing, respectively) and Coll2 ( $\mathrm{p}=0.011$ and $\mathrm{p}=0.004$ for treatment before and after plowing, respectively).

\section{Effect of Plowing on GAG Release}

To determine if GAG release after plowing was mechanically or enzymatically induced, MMP activity was inhibited by GM6001 treatment of the cartilage explants (i.e. controls and plowed samples) before and after plowing. As shown in figure 4, all samples showed increasing actinomycin $\mathrm{D}$ treatment. Black bars: immediately after plowing, the cartilage strips were incubated for $2 \mathrm{~h}$ with actinomycin D. For all experiments, the expression levels (normalized against the GAPDH and 18S-rRNA genes) were normalized to those of the controls (i.e. nonloaded, free-swelling explants, either untreated or treated with actinomycin D. Each experiment was from a separate bovine nasal septum $(n=3)$, and 3 similarly treated explants were pooled for RNA extraction in each. ${ }^{*} \mathrm{p}<0.05$.

GAG release over time with excellent coefficients of determination $\left(\mathrm{R}^{2}\right.$ values $\left.\geq 0.9\right)$.

GAG release from plowed samples, independently of the GM6001 treatment, was higher than that from the corresponding controls.

In addition, the GAG release from the control samples showed no statistically significant difference, but the plowed samples treated with GM6001 or not treated showed statistically significant differences of GAG release over time (for day 1: $\mathrm{p}=0.011$, day $2: \mathrm{p}=0.003$, day 3 : $p=0.018$ and day 4: $p=0.012$ ). These results suggest that GAG release is due to both a mechanical and an enzymatic component, and that under plowing conditions, the enzymatic component is dominant. 


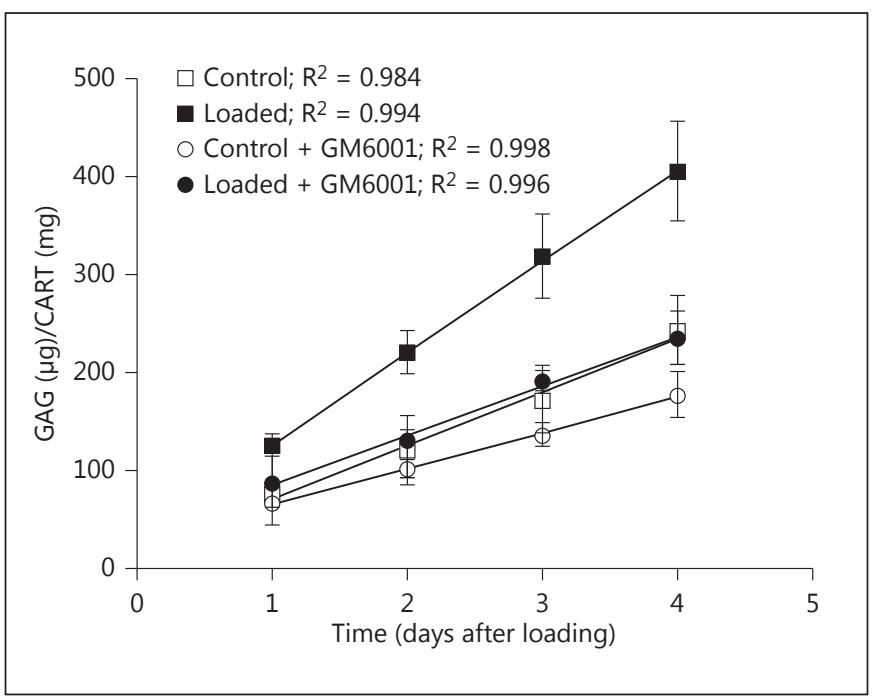

Fig. 4. GAG release into the medium from 100-newton plowed cartilage and control on days 1-4 after plowing (3 experiments for each condition and each time point). GAG release for both loaded and control explants normalized to the corresponding cartilage wet weight (full squares: GAG release from plowed explants not treated with GM6001, empty squares: GAG release from control cartilage not treated with GM6001, full circles: plowed cartilage treated with GM6001 and empty circles: control cartilage treated with GM6001).

\section{Discussion}

In this study, we performed plowing of pristine cartilage strips and demonstrated that, in vitro, this causes cell death at the surface of the explants, changes the chondrocyte gene expression and also induces GAG release by activating catabolic enzymes.

Bovine nasal cartilage was selected as model tissue because of its unique features: it is pristine (not previously subjected to any mechanical load), has homogeneously distributed chondrocytes and, along with being easily available in big quantities, it can be easily shaped. In addition, it was recently demonstrated that bovine nasal cartilage behaves as a biphasic material and has viscoelastic responses to dynamic forces [Colombo et al., 2013].

During jaw opening/closing, the TMJ cartilage disk is mainly affected by the plowing forces that are the dominant components of the tractional force. The plowing of the disk results from the combination of an applied normal force and the sliding of the condyle.

The plowing parameters used in this study were comparable to those encountered under physiological conditions. The indenter speed was chosen after evaluation of
TMJ recordings performed during rhythmic jaw opening and closing [Gallo et al., 2000]. Interestingly, this speed value can also be compared to that estimated in other joints, such as in the knee during walking [Waldman and Bryant, 1997]. The applied normal forces were chosen according to the study of Sellers and Crompton [2004], showing that $100 \mathrm{~N}$ corresponds to the condylar TMJ force occurring during biting.

We provided here a model of cell death caused by plowing. We found that the plowing of cartilage strips induces cell death progressively, increasing along with the magnitude of applied normal force. The fact that dead cells were mainly detected at the surface of the explants suggests that chondrocytes located closer to the surface are more exposed to mechanical stress and are therefore more vulnerable than those in the deeper zones. Furthermore, qRT-PCR revealed that MMP-3 upregulation, similar to the superficial cell death observed, is dependent on the magnitude of the applied mechanical stress and that it decreases over a 24-hour equilibration period after plowing (fig. 2). In contrast, the mRNA content for Agg, TIMP-1, Fn, Coll1 and Coll2 remained unchanged compared to the control values. As active MMP-3 digests collagens, proteoglycans and other extracellular matrix proteins as well as activating the proforms of other MMPs and aggrecanase II [Murphy et al., 2002; Cawston and Wilson, 2006; Echtermeyer et al., 2009], our results suggest that plowing causes an increase in catabolic activities starting at $25 \mathrm{~N}$ of applied normal force.

It is well known that cartilage has a poor intrinsic healing capacity [Lima et al., 2004]. Nevertheless, after an injury, the healthy chondrocytes promote a remodeling process that consists of the elimination of the damaged matrix and the rebuilding of new matrix [Treadwell et al., 1991]. We could thus suppose that in the plowed cartilage, viable chondrocytes start to remodel the matrix by producing MMP-3, as shown by qRT-PCR experiments, in order to clear space for cell ingrowth and/or the deposition of newly synthesized proteins.

Application of the transcription inhibitor actinomycin D before plowing reduced the MMP-3 mRNA content to its control level (fig. 3a), indicating that early events during the 2-hour plowing period induce an increase in MMP-3 mRNA transcription. Under the same conditions, the mRNA of TIMP-1, Coll1, Agg, Fn and Coll2 were increased by a factor of 2 . Assuming that, in the presence of actinomycin $\mathrm{D}$, the transcription was fully inhibited (as in the case of MMP-3), these results suggest that all these mRNAs were, to a certain extent, prevented from degradation during plowing and that this process is, in 
turn, dependent on transcription. Considering that all these mRNA content data were compared to controls that did not undergo plowing, it is suggested that plowing has an additional, so far unknown, stabilizing effect on mRNAs for TIMP-1, Coll1, Agg, Fn and Coll2, that depends on active transcription. It could also be that actinomycin D itself stabilizes certain mRNA species. The degradation of mRNA is an essential determinant in the regulation of gene expression, and it can be modulated in response to environmental signals by cis-acting elements and trans-acting factors that contribute to mRNA regulation decay [Tourriere et al., 2002; Simon et al., 2006]. In addition, it has already been reported that actinomycin D has a stabilizing effect on the mRNA transcription of TIMP-1 by affecting trans-acting factors involved in TIMP-1 mRNA degradation [Gardner et al., 2006].

This stabilizing effect or artifact of actinomycin D could also account for the 2-fold increase in Agg, Coll2 and Fn mRNA when applied for $2 \mathrm{~h}$ upon completion of plowing.

The 7- to 8-fold increase in mRNA content for TIMP1 and Coll1, however, suggests that both species increased during plowing and that, in the absence of actinomycin $\mathrm{D}$, they decreased to control levels during the 2-hour equilibration period. This hypothesis would require a postplowing half-life of TIMP-1 and Coll1 mRNA of $<1 \mathrm{~h}$. In contrast, the half-life of MMP-3 mRNA is about $24 \mathrm{~h}$ (fig. 2). Whether or not plowing can induce factors that are able to modulate the half-life of specific mRNA species such as TIMP-1 or Coll1 cannot be definitively determined from these results.

In essence, we have observed three patterns of transcription regulation. The first is of the MMP-3 mRNA type, the transcription of which is induced during plowing. The second includes TIMP-1 and Coll1, the mRNA decay of which occurs early in the equilibration period after plowing. The third applies to Agg, Fn and Coll2, the basal transcription of which is either stabilized or unaffected by plowing.

Furthermore, we showed that the amount of GAG release from the plowed cartilage strips was higher than the corresponding release from control explants [DiMicco et al., 2004; Lin et al., 2004], and that this release was due to both mechanical damage and enzymatic activity. Since GAG release was also observed after the treatment of plowed cartilage with GM6001, we could state that plowing provokes the mechanical degradation of the cartilage matrix. This finding is also supported by two macroscopic events, namely, the bending of the strip during plowing (due to the fact that the strip is glued by the extremities to the support) and the increase in the length of the cartilage strips. The cartilage strip deformation strongly depended on the applied normal force during plowing. An increase in the entire length of the sample was observed at all the applied forces. In more detail, for samples plowed with the normal forces of 25,50 and $100 \mathrm{~N}$, a length increase was measured of $0.5 \pm 0.07,1.0 \pm 0.06$ and $1.9 \pm 0.29 \mathrm{~mm}$, respectively; this corresponded with a relative strip elongation of $0.7 \pm 0.3,1.5 \pm 0.2$ and $3.0 \pm 0.7 \%$ for 25,50 and $100 \mathrm{~N}$, respectively.

Both observations suggest that plowing could damage the collagen fibers, causing, in turn, a GAG release [DiMicco et al., 2004]. Nevertheless, given that even after 1 day of equilibration, the GAG release from plowed cartilage was 30\% higher than in the plowed cartilage treated with GM6001, we could conclude that GAG loss is also due to the catabolic activity of MMPs that are activated during plowing. Thus, the increase in MMP mRNA induced by plowing, as in the case for MMP-3, yields an increase in MMP activity.

When cartilage explants are subjected to a static compression with an applied pressure $>0.5 \mathrm{MPa}$, the chondrocyte metabolism is already irreversibly compromised after $1 \mathrm{~h}$ [Sah et al., 1989; Valhmu et al., 1998]. The pressure during the 100-newton plowing has been calculated to be around $2.5 \mathrm{MPa}$, taken from measurements of the contact area between the condyle and the cartilage. This finding suggests that plowing with a high applied pressure is not as harmful as a static compression. In contrast to what happens during static compression where the flow of nutrients is limited, during plowing, the sliding of the indenter not only mixes the surrounding medium and thus facilitating the exchange of molecules and ensuring better cartilage homeostasis, it also squeezes fluid out of the cartilage which is subsequently replenished by new medium.

The response of cartilage explants to mechanical injuries has been extensively investigated in vitro, but, to our knowledge, plowing experiments where the indenter simultaneously applies a compression and slides on the cartilage explants have never been reported.

On the basis of the obtained results, we deduce that plowing with an applied normal force of $100 \mathrm{~N}$ and an indenter speed of $10 \mathrm{~mm} / \mathrm{s}$ causes cell death of the chondrocytes closer to the surface as well as matrix damage, observed as GAG loss. In addition, in healthy chondrocytes, plowing promotes the production and activation of catabolic enzymes like MMP-3 and, $2 \mathrm{~h}$ after plowing, shows no effect on anabolic genes like Agg, Coll1, Coll2 and Fn. 


\section{Acknowledgements}

We are grateful to Vera Colombo and Stefan Erni for developing and installing the RPETS and the tank heating system. This study was supported by the Swiss National Science Foundation (grant No. 325200-110067), Prof. L.M. Gallo's financial start-up package and the standard financial plan of the University of $\mathrm{Zu}$ rich.

\section{References}

Barbosa, I., S. Garcia, V. Barbier-Chassefiere, J.P. Caruelle, I. Martelly, D. Papy-Garcia (2003) Improved and simple microassay for sulfated glycosaminoglycans quantification in biological extracts and its use in skin and muscle tissue studies. Glycobiology 13: 647-653.

Cawston, T.E., A.J. Wilson (2006) Understanding the role of tissue degrading enzymes and their inhibitors in development and disease. Best Pract Res Clin Rheumatol 20: 983-1002.

Chen, C.T., M. Bhargava, P.M. Lin, P.A. Torzilli (2003) Time, stress, and location dependent chondrocyte death and collagen damage in cyclically loaded articular cartilage. J Orthop Res 21: 888-898.

Colombo, V., M. Čadová, L.M. Gallo (2013) Mechanical behavior of bovine nasal cartilage under static and dynamic loading. J Biomech 46: 2137-2144.

Colombo, V., M.R. Correro, R. Riener, F.E. Weber, L.M. Gallo (2011) Design, construction and validation of a computer controlled system for functional loading of soft tissue. Med Eng Phys 33: 677-683.

-Davidson, R.K., J.G. Waters, L. Kevorkian, C. Darrah, A. Cooper, S.T. Donell, I.M. Clark (2006) Expression profiling of metalloproteinases and their inhibitors in synovium and cartilage. Arthritis Res Ther 8: R124.

DiMicco, M.A., P. Patwari, P.N. Siparsky, S. Kumar, M.A. Pratta, M.W. Lark, Y.J. Kim, A.J. Grodzinsky (2004) Mechanisms and kinetics of glycosaminoglycan release following in vitro cartilage injury. Arthritis Rheum 50: 840-848.

Ding, L., E. Heying, N. Nicholson, N.J. Stroud, G.A. Homandberg, J.A. Buckwalter, D. Guo, J.A. Martin (2010) Mechanical impact induces cartilage degradation via mitogen activated protein kinases. Osteoarthritis Cartilage 18 : 1509-1517.

Dossumbekova, A., M. Anghelina, S. Madhavan, L. He, N. Quan, T. Knobloch, S. Agarwal (2007) Biomechanical signals inhibit IKK activity to attenuate NF-kappaB transcription activity in inflamed chondrocytes. Arthritis Rheum 56: 3284-3296.

Echtermeyer, F., J. Bertrand, R. Dreier, I. Meinecke, K. Neugebauer, M. Fuerst, Y.J. Lee, Y.W Song, C. Herzog, G. Theilmeier, T. Pap (2009) Syndecan- 4 regulates ADAMTS- 5 activation and cartilage breakdown in osteoarthritis. Nat Med 15: 1072-1076.

- Fitzgerald, J.B., M. Jin, A.J. Grodzinsky (2006) Shear and compression differentially regulate clusters of functionally related temporal transcription patterns in cartilage tissue. J Biol Chem 281: 24095-24103.
Gallo, L.M. (2005) Modeling of temporomandibular joint function using MRI and jaw-tracking technologies-mechanics. Cells Tissues Organs 180: 54-68.

Gallo, L.M., G. Chiaravalloti, L.R. Iwasaki, J.C. Nickel, S. Palla (2006) Mechanical work during stress-field translation in the human TMJ. J Dent Res 85: 1006-1010.

Gallo, L.M., J.C. Nickel, L.R. Iwasaki, S. Palla (2000) Stress-field translation in the healthy human temporomandibular joint. J Dent Res 79: $1740-1746$.

- Gardner, J., K. Borgmann, M.S. Deshpande, A. Dhar, L. Wu, R. Persidsky, A. Ghorpade (2006) Potential mechanisms for astrocyteTIMP-1 downregulation in chronic inflammatory diseases. J Neurosci Res 83: 12811292.

Griffin, T.M., F. Guilak (2005) The role of mechanical loading in the onset and progression of osteoarthritis. Exerc Sport Sci Rev 33: 195200.

Jeffrey, J.E., R.M. Aspden (2007) Cyclooxygenase inhibition lowers prostaglandin E2 release from articular cartilage and reduces apoptosis but not proteoglycan degradation following an impact load in vitro. Arthritis Res Ther 9: R129.

Kurz, B., A.K. Lemke, J. Fay, T. Pufe, A.J. Grodzinsky, M. Schunke (2005) Pathomechanisms of cartilage destruction by mechanical injury. Ann Anat 187: 473-485.

Lane, S.R., M.C. Trindade, T. Ikenoue, M. Mohtai, P. Das, D.R. Carter, S.B. Goodman, D.J. Schurman (2000) Effects of shear stress on articular chondrocyte metabolism. Biorheology 37: 95-107.

Lee, J.H., J.B. Fitzgerald, M.A. DiMicco, A.J. Grodzinsky (2005) Mechanical injury of cartilage explants causes specific time-dependent changes in chondrocyte gene expression. Arthritis Rheum 52: 2386-2395.

Lima, E.G., R.L. Mauck, S.H. Han, S. Park, K.W. Ng, G.A. Ateshian, C.T. Hung (2004) Functional tissue engineering of chondral and osteochondral constructs. Biorheology 41: 577590.

Lin, P.M., C.T. Chen, P.A. Torzilli (2004) Increased stromelysin-1 (MMP-3), proteoglycan degradation (3B3- and 7D4) and collagen damage in cyclically load-injured articular cartilage. Osteoarthritis Cartilage 12: 485496.

Murphy, G., V. Knauper, S. Atkinson, G. Butler, W. English, M. Hutton, J. Stracke, I. Clark (2002) Matrix metalloproteinases in arthritic disease. Arthritis Res 4: S39-S49.
Palla, S., L.M. Gallo, D. Gossi (2003) Dynamic stereometry of the temporomandibular joint. Orthod Craniofac Res 6: 37-47.

Patwari, P., M.N. Cook, M.A. DiMicco, S.M. Blake, I.E. James, S. Kumar, A.A. Cole, M.W. Lark, A.J. Grodzinsky (2003) Proteoglycan degradation after injurious compression of bovine and human articular cartilage in vitro: interaction with exogenous cytokines. Arthritis Rheum 48: 1292-1301.

Patwari, P., J. Fay, M.N. Cook, A.M. Badger, A.J. Kerin, M.W. Lark, A.J. Grodzinsky (2001) In vitro models for investigation of the effects of acute mechanical injury on cartilage. Clin Orthop Relat Res 391: S61-S71.

Sah, R.L., Y.J. Kim, J.Y. Doong, A.J. Grodzinsky, A.H. Plaas, J.D. Sandy (1989) Biosynthetic response of cartilage explants to dynamic compression. J Orthop Res 7: 619-636.

Sauerland, K., J. Steinmeyer (2007) Intermittent mechanical loading of articular cartilage explants modulates chondroitin sulfate fine structure. Osteoarthritis Cartilage 15: $1403-$ 1409.

Sellers, W.I., R.H. Crompton (2004) Using sensitivity analysis to validate the predictions of a biomechanical model of bite forces. Ann Anat 186: 89-95.

Simon, E., S. Camier, B. Seraphin (2006) New insights into the control of mRNA decapping. Trends Biochem Sci 31: 241-243.

-Torzilli, P.A., M. Bhargava, S. Park, C.T. Chen (2010) Mechanical load inhibits IL-1 induced matrix degradation in articular cartilage. Osteoarthritis Cartilage 18: 97-105.

Tourriere, H., K. Chebli, J. Tazi (2002) mRNA degradation machines in eukaryotic cells. Biochimie 84: 821-837.

Treadwell, B.V., M. Pavia, C.A. Towle, V.J. Cooley, H.J. Mankin (1991) Cartilage synthesizes the serine protease inhibitor PAI-1: support for the involvement of serine proteases in cartilage remodeling. J Orthop Res 9: 309-316.

Valhmu, W.B., E.J. Stazzone, N.M. Bachrach, F. Saed-Nejad, S.G. Fischer, V.C. Mow, A. Ratcliffe (1998) Load-controlled compression of articular cartilage induces a transient stimulation of aggrecan gene expression. Arch Biochem Biophys 353: 29-36.

Verteramo, A., B.B. Seedhom (2007) Effect of a single impact loading on the structure and mechanical properties of articular cartilage. J Biomech 40: 3580-3589.

Waldman, S.D., J.T. Bryant (1997) Dynamic contact stress and rolling resistance model for total knee arthroplasties. J Biomech Eng 119: 254-260. 